\title{
Anat Pershitz \\ https://orcid.org000-0001-6270-9494 \\ (Tel Aviv) \\ THE PROSPECTIVE STATUS OF WOMEN IN ISRAEL FOLLOWING A CLASH BETWEEN THE FEMINIST AND RELIGIOUS REVOLUTIONS IN THE ISRAELI ARMY
}

\begin{abstract}
In the past decade, the Israeli Army (IDF) has been undergoing simultaneously two 'social revolutions': a 'feminist revolution' and a "religious revolution". The two revolutions have different and conflicting ideologies causing a clash of values. Feminist values demand the integration of women in the army without gender separation, whereas religious principles require modesty and gender separation. At the moment, in practice, religious values which undermine women's equal opportunities in the army outweigh democratic values. If the secular women and men in Israeli society will not act to deprive the IDF of its unofficial and unauthorized role of balancing conflicting values in society, the status and roles of women in the army will be downgraded, directly impacting gender inequality in the employment market.
\end{abstract}

\section{Key words}

Gender and power, feminism, gender discrimination, Israeli Women and the Labor Market, employment opportunities, the status of women at work, equal opportunities at work, the Israeli Army (IDF), the ultra-Orthodox and the IDF 
The right to equality between the sexes is derived from human dignity. Human rights should be applied equally for all people, without difference. However, tradition, prejudices, as well as social, economic, and political interests have led to the exclusion of women from the general definition of "human rights", and to classifying them as a "special case" in the discourse on human rights. This repression of women, in theory and in practice, is a reflection of the inequality between the sexes around the whole world ${ }^{1}$.

Equality between the genders, does not mean formal equal standards, that ignore the different starting points and the fundamental differences between the sexes. The discussion of fundamental equality recognizes and acknowledges differences between women and men. The lives of people need to be equal according to the basic criteria so as to get as close as possible to the ideal of social justice ${ }^{2}$. Therefore, the principle of equality includes a comparison of the conditions at birth, and the possibility of social mobility in order to allow equality of opportunity, and freedom of choice. Equality in this sense means having the same attitude towards those who are similar and a different attitude towards those who are different according to their degree of variation $^{3}$. Applying such a standard will enable women to develop according to their abilities and skills in a relevant and non-stereotypical manner.

Although in Israel there is extensive legislation for the rights of women in many different areas, many of the laws pertain to institutional aspects, and not to personal equality at a deeper level. Issues that are defined as problematic (such as the human right to get married and to get divorced) are pushed to the side, and are perceived as eroding Jewish cohesion. Therefore, the aspiration, the desire, and the commitment to equality become purely declarative, and are not embodied in practice 4 .

Structured inequality towards women in Israeli society derives primarily from the political system in Israel, which is characterized by the need to establish a coalition with the religious parties. Currently, twenty-one of the total 120 Knesset members (the Israeli parliament) are drawn from one of the religious parties. As a result, the power of the religious parties to influence the social fundamental values of society in the spirit of the Jewish codex, the Halacha ${ }^{5}$,

\footnotetext{
${ }^{1}$ Hosken 1981, p. 9.

${ }^{2}$ Pinto 2013, p. 134.

${ }^{3}$ Ibidem, p. 119.

${ }^{4}$ Wilmovsky and Tamir 2013, p. 36.

${ }^{5}$ Irshai 2018, pp. 301-326.
} 
which is not commensurate with the liberal democratic values on the equality of the woman ${ }^{6}$, far exceeds their electoral power.

Another significant factor that influences the structural inequality towards women in Israeli society is the prolonged political-military conflict, which has accompanied the State of Israel from the day it was established in 1948. The conflict overshadows all other aspects of public life in the State of Israel, and is at the top of the public agenda. It leads Israeli society to adopt military norms based on masculine values, where women are relegated to margins, and are excluded from active participation in the setting of the political agenda. Social topics are not at the center of attention, and basic questions on the civic issues in general, and the status of the woman in particular, do not usually occupy the public agenda ${ }^{7}$.

In recent years, the two factors were combined. In parallel with the steadily increasing number of units open to the service of women, the importance of the religious soldiers among the combat officers is rising, and the number of Ultra-Orthodox ${ }^{8}$ recruits is increasing. This has come about as a result of increased political and social power of the nationalist religious sector, and the adoption a state policy to integrate the Ultra-Orthodox community into the mainstream society. The conflict between the gender revolution in the IDF, and the demands of the religious soldiers has become unavoidable.

The principles guiding the integration of women into the army were reflected during the establishment of Israel in the words of David Ben-Gurion, Israel's first prime minister: "(...) The woman is not disqualified of any service, she is not deprived of any right, and she is not exempt from any obligation, unless it harms her motherhood"9. Ben-Gurion's position expresses the ambivalent concept of integrating women into the military system, a concept in which motherhood overcomes security needs ${ }^{10}$. With that, Ben-Gurion established women's military service as an integral part of the Israel Defense Forces, but defined a clear gender division between male and female soldiers. Unlike men, who were directed and assigned to combat roles, women were mostly recruited to units intended for supporting the fighting men, and assigning them to different operational positions ${ }^{11}$. As Karin Carmit Yefet

\footnotetext{
${ }^{6}$ Jerby 1996, p. 24.

${ }^{7}$ Ibidem, p. 27.

${ }^{8}$ Spiegel 2007, p. 74

${ }^{9}$ Jerby 1996, p. 71.

${ }^{10}$ Ibidem.

${ }^{11}$ Yefet, Almog 2016, p 257.
} 
and Shulamit Almog summed it up: "The army of the first generation is an army of men serving the people, and women serving the men"12.

This stereotypical perception has changed over the years. The turning point was the High Court of Justice's ruling in 1995, which determined that women are entitled to formal and substantive equality in their military service, and that the army's policy of closing-off the Flight Academy to is unacceptable. In its ruling, the court ordered the IDF to integrate women into its ranks not only in accordance with security needs derived from current needs, but also subject to a substantive commitment to equality ${ }^{13}$. In the words of Justice Tova Strasberg-Cohen,

In a clash between the value of equality and the value of national security as a result
of the needs of the army, state security can be seen as a preferred value and of
a higher status than the value of equality, despite the importance of the latter. But
the security of the state is not a magic word, and does not take priority in all cases
and under any circumstances, and is not the same at all levels of security ${ }^{14}$.

The court ruling led to the passing of an amendment in January 2000 of the Defense Service Law, adding to the Proper Service Ordinance a section which states that all positions in the army are open to women, unless it conflicts with the nature and character of the position. In this way, the Knesset enshrined equal opportunities for women in the IDF with a special law ${ }^{15}$. Following this law, the army removed some of the limitations on women in combat roles, the number of women assigned to clerical and administrative positions has been reduced, and gender mainstreaming was applied to some of the organizational processes of sorting and embedding solders. These changes broke down the accepted gender separation and led to unseparated service of men and women in joint units ${ }^{16}$.

The integration of women into various units led to a clash between two social revolutions in the IDF: the "feminist revolution" and the "religious revolution", which, as mentioned, began earlier and was reflected in an increase in the enrollment rate of religious youth. Both groups increased their presence in the combat units, with each group coping with their own cultural barriers. In the case of women, there was also the need to grapple

${ }^{12}$ Ibidem.

${ }^{13}$ Shafran-Gitelman 2018.

${ }^{14}$ High Court 4541/94 Miler against the defense minister, p. 42.

${ }^{15}$ Levi 2012.

${ }^{16}$ Sasson-Levi, Amram-Katz 2007, p. 132. 
with barriers anchored in institutional arrangements, which prevented full integration into the various positions in the army ${ }^{17}$.

The increased presence of religious young people in the army has created a process of de-legitimization of the presence of women in the army ${ }^{18}$. For the religious soldiers, segregation between the sexes is mandatory component in the service of the principle of modesty - a principle which is becoming central to Israeli religious society. According to Harel and Shenark ${ }^{19}$ gender separation is derived, among other things, from the halachic prohibition of looking at the opposite sex, and the mixing of the sexes, so as to prevent lust or desire; It enables both sexes to avoid contact with each other, thus preserving their modesty and avoiding reciprocated harm. But, in fact, there is no reciprocity here. The prohibition on looking at the opposite sex applies only to men, while the laws of modesty are aimed at women. The masculine bias of the discourse of modesty creates clear power relations, since in the context of halachic society, gender separation means pushing women out of public power positions ${ }^{20}$. As Statman points out

Inequality leads to a violation of dignity, in the sense of humiliation, when the basis of inequality is a world view (...) according to which the members of the group who are the subject of the unequal treatment are not worthy of being full members of the society because of their gender, race, religion, and so ${ }^{21}$.

And so, the worldview that guides gender separation also shapes its implications. The state's drive to integrate the Ultra-Orthodox into the military service, higher education, and the labour market leads to systematic exclusion of women from the public space in Israel ${ }^{22}$. The religious radicalization is steadily increasing in the non-Ultra-Orthodox religious public, and with it comes the demand to further exclude women from places in the public space. The ultra-Orthodox are unwilling to study or work together with women. The separation begins at kindergarten and continues in academia. Students in the ultra-Orthodox and religious sectors study in separate educational systems for boys and girls. As a result, the ultra-Orthodox public has not interacted over the years with members of the other gender ${ }^{23}$. The rise in the

\footnotetext{
${ }^{17}$ Levi 2008, p. 1.

${ }^{18}$ Levi 2012.

${ }^{19}$ Harel, Shenrach 2003, p. 84.

${ }^{20}$ Sasson-Levi 2013, p. 120.

${ }^{21}$ Statman 2001, p. 581

${ }^{22}$ Eran-Yonah, Padan 2018, p.99.

${ }^{23}$ Eran-Yonah, Padan 2018, p. 97.
} 
dominance of the religious minority in Israeli society and politics only strengthens the phenomenon.

Although military service in Israel is mandatory, the enlistment rate for the army is declining for various reasons. Therefore, to fill its ranks, the military recruits an increasing number of religious soldiers thereby changing the demographic composition of the officer corps and combat units. The religious elements in the military are empowered, and with them, the influence of religious-cultural norms on the nature and functioning of the military is strengthening ${ }^{24}$.

The result is that religious and Ultra-Orthodox groups carve for themselves enclaves in the military, "clean" of women ${ }^{25}$. Consequently, there is a growing constraint on equal integration of women, not only into combat roles, but also into training positions, which, in the past, have been opened to women. This phenomenon undermines the state-based character of the military: the value of equality for all, and the nature of the IDF as a framework common to all the sectors, gender, and groups in Israeli society ${ }^{26}$. Furthermore, this trend runs counter to the fundamental principles of Israeli law, inscribed in the Basic Law: Human Dignity and Liberty and the Basic Law on Freedom of Occupation, which states that all work must be open to men and women alike. There is no constitutional dispute over the general principle that prohibits the exclusion of women form any place of work and from any position. This principle was reinforced when Judge Dorner stated in her ruling that "the requirement to take into account the special needs of women is similar to the requirement to take into account a person's religious beliefs" 27 . Although these theoretical principles are clear, in practice, the scope of the prohibition against the exclusion of women in the army is not always clear. In addition to open and direct exclusion of women caused by the programs of integration of the Ultra-Orthodox men into the military service, much of the exclusion of women is concealed. An examination of the actual integration of women into the military shows that in many positions that are not formally closed to women, their percentages are very low ${ }^{28}$.

Military service (or abstention from it) has a significant impact on all citizens in Israel on the personal, social, and especially economic level, as it

\footnotetext{
${ }^{24}$ Levi 2012.

${ }^{25}$ Eran-Yonah, and Padan 2018, p. 98.

${ }^{26}$ Ibidem.

${ }^{27}$ Pinto 2013, p. 136.

${ }^{28}$ Ibidem.
} 
relates to the cultural, political, social and economic characteristics of Israeli society. Military service is a resource used in civilian life, lasting even many years after the discharge from the military service. The service influences the employment opportunities in Israel, can serve as a channel for social mobility, and can contribute to narrowing gender gaps.

The approach that the army contributes to the democratic and egalitarian character of society and the state by providing a level playing field entry to Israeli society has receded in recent years. It has been replaced by a critical approach that regards the army as a social mechanism that reproduces the hierarchical structure of society. According to this approach, the army operates mechanisms of inclusion and exclusion that are part of the mechanisms of the Israeli society ${ }^{29}$ and are based on different dimensions of identity, including gender, sexuality and religion ${ }^{30}$. Military service is considered as means and a measure of the individual's social integration. Moreover, the type and quality of the positions in the service are a test of the individual's ability to integrate socially. Service in the army confers on the individual formal rights alongside symbolic capital, and these, in turn, shape the individual's prospects of integration into the civilian employment market ${ }^{31}$.

Gender inequality has always been rooted in the religion, tradition and mentality of Israeli society, with gender distinctions being used to denote power relations and justify the current social order. Although the number of women and men in society is almost equal, the differences in status between them led to the fact that women are considered a minority group in society. The very definition of women as a "minority" indicates their marginality. The majority-minority relations assume the preference of the majority (men) and the marginality of the minority (women). This inferior social position affects the level of visibility of women in the public arena, and makes it difficult for them to integrate into the public sphere. Gender inequality is intertwined with the division of labor, authority relationship and the daily interpersonal interactions of the work routine. Once these norms are institutionalized, they seem entirely rational and objective. Where men are benefiting from gender division, they are also active in perpetuating $\mathrm{it}^{32}$. The result is that women encounter a glass ceiling that blocks their progress in the workplace and on the social ladder. They also confront the phenomenon of the "glass eleva-

\footnotetext{
${ }^{29}$ Helman 2001, p. 314.

${ }^{30}$ Krumer-Nevo, Malka, and Moredechayev 2013, p. 314.

${ }^{31}$ Levy 2003, p. 320.

${ }^{32}$ Izraeli 1999, p. 170.
} 
tor" ${ }^{33}$, the situation in which, even in "female" domains in the military, the senior positions are staffed by men $^{34}$.

The impact of the labor market on the state of gender inequality is crucial. Employment segregation is one of the central expressions of inequality and it also creates gaps in income and promotion opportunities ${ }^{35}$. In Israel, gender inequality is evident in the labor market: a large number of women are still employed in education and in very low percentages in technological fields ${ }^{36}$. The findings show that high-tech companies are discriminating between men and women even more than other industries ${ }^{37}$.

The Hypothesis is that military service in Israel further increases the gender polarization in the labor market. The IDF is an inseparable part of Israeli society, and, as such, military service has an influence on social stratification and the social gaps. A prestigious role in the army indicates one's position in the social ladder. Prestigious positions in the army can also serve as a stepping stone for successful civilian careers: Employers and firms prefer experienced workers who know the field.

In addition, it seems that many jobs appointments in Israel, both in the public sector and the private sector, rely on an informal network of recommendation by friends and acquaintances. This nepotism of sorts is considered as an effective way of recruitment for work and promotion, as it is a cheaper, more focused and a shorter process. The majority of organizations note that most of their positions are manned via this recommendation system. On average, $35 \%$ of all new recruits in the different organizations are hired through the use of this method ${ }^{38}$. This hiring method encourages the recruitment of workers from closed circles and does not allow for the employment of workers from varied sexual, religious, age and nationality backgrounds. The result is the exclusion of entire populations from the employments pool, including the female population, because they are excluded from desirable positions in the army.

One's level of security clearance can also affect integration into the Israeli employment market. In Israel, there are security related companies and businesses that requires a high security clearance. The type of information to

\footnotetext{
${ }^{33}$ Naveh, Shor 2001, p. 14.

${ }^{34}$ Ibidem, p. 15.

${ }^{35}$ Carmon 2016.

${ }^{36}$ Fuchs 2016, p. 87.

${ }^{37}$ Orpaz 2015.

${ }^{38}$ Rozen 2017, p. 12.
} 
which one has access in the military service determine the level of security clearance, and, hence, such companies attach great importance to the military service. The lack of a high enough security clearance level can preclude a job offer in many security related occupations.

The gendered processes by which men and women are integrated into the army intensify the apparent differences between them and push women to the margins, and lead to unequal opportunities for social mobilization both within the army and in civilian life ${ }^{39}$. The benefits men derive from military service are converted into advantages in the labor market. Military elites easily slip into elite positions in civilian life, where they contribute to the growth of gender inequality and the perpetuation of gender-specific processes in the military ${ }^{40}$. Brooke ${ }^{41}$ sees an Israeli version of the "Matthew effect", according to which the difference in the potential for advancement in work among groups and individuals increases as they progress in life. In his opinion, the Matthew effect is the engine that causes the increase in inequality in society.

Today, it seems that the situation of women in the army is better than ever. The ongoing feminist effort has succeeded in promoting a more egalitarian service model for women in the IDF. As the army is opening more positions to combat units for women, an increasing number of women are responding to the challenge. Future female soldiers will have greater opportunities to serve in various types of service, and fulfill a variety of roles which could enrich their world. There is already evidence that discharged women soldiers, who prior to their military service had no inclination to computers, go on to study computer science, and software engineering, after being exposed to this world in the IDF. Women soldiers can also serve in elite units, and in a variety of technical, research, and technological roles. Female soldiers proved that they can be integrated into an infantry unit that combines both male and female fighters, and serve as instructors who train fighters in the use and operation of weapons, military tools, missiles and tanks ${ }^{42}$.

The worldwide "me too" campaign, which has also reached Israel, intensified the sense that Israeli society is undergoing a process of a slow but profound change. Diverse groups of women with political self-awareness are

\footnotetext{
${ }^{39}$ Izraeli 1999, p. 182.

${ }^{40}$ Ibidem, p. 183.

${ }^{41}$ Brooke 2012.

${ }^{42}$ IDF 2019.
} 
active in different arenas to redefine gender, gender inequality, and gender relations. But even more, these groups challenge dominant political perceptions and offer alternative ways of seeing the social order, allowing women to become one of the main forces in the emerging civil society ${ }^{43}$. An expression of this change can also be seen in the growing number of women representatives in the Knesset. In the Knesset that was elected in 2015, there were thirty-four women representatives (constituting 28.3 percent of the total), compared to twenty-seven women in the previous Knesset (elected in 2013), twenty-five women in the Knesset elected in 2009, and eighteen women in the Knesset elected in $2006^{44}$. Thus, the rise in the women representation is not coincidental, and has occurred both in right-wing and left-wing parties. This change is also reflected in a new public discourse that makes room for women to be heard. In addition, it seems that, today, social issues are being put on the agenda, and are less likely to be silenced in favor of a security agenda.

However, simultaneously, in recent years, there has been a growing radicalization of religion that is expressed in daily life, and especially in the IDF. The army has responded to demands of religious soldiers in a growing number of cases. Perhaps, the separate cases may not seem significant. However, if the individual cases are treated as a whole, they indicate the extent to which the different lifestyles which divide the religious and secular communities, are emerging in the army ${ }^{45}$. This situation is likely to escalate, since studies show that when the law is inconsistent with accepted cultural values, its interpretation is determined by these values and not vice versa ${ }^{46}$. Recently, the Proper Integration Ordinance of the IDF was replaced with the Joint Service Ordinance to accommodate the integration of religious soldiers. In the new ordinance, the principle of equality between genders, including an equal right to fill any role in military was removed ${ }^{47}$. Therefore, it is reasonable to expect that in the struggle within the army between democratic values of the rights of the individual for human dignity and liberty, and the religious values that oppose women military service altogether, or allow it only on condition of maximum separation between the sexes - religious values will prevail. Women in the army will be the first to be hurt by such a development,

${ }^{43}$ Herzog 2006, p. 191.

${ }^{44}$ Knesset 2019.

${ }^{45}$ Cohen, Orr-Yisrael 2001, p. 138.

${ }^{46}$ Jerby 1996, p. 93.

${ }^{47}$ Levy 2018. 
and the harm to their status will have a long-term impact on their professional future and their status in society.

Against this background, the secular public, which still constitutes the majority of the Israeli public, must not allow an extreme minority to lead the discourse. It must make sure that another, more rational voice will be heard. Although discourse in the public sphere is determined by the powerful, according to Foucault ${ }^{48}$, power does not rest with a specific group in society, but in the society as a whole. There is a possibility that changing the discourse in society will create new concepts of knowledge, which, in turn, will create a new reality and give rise to new forces in society. It seems that in this period of increasing women's awareness of their abilities and social status, technological improvement enables the dissemination of information, and the creation of new forces that can change and disseminate a new discourse.

The women's movement in Israel is working in this direction. It focuses on redefining the scope of social issues, problems and hardships. The movement puts new issues on the public agenda, and rearranges the political space, while exposing the mechanisms of gender exclusion and politicization of the interconnected private and public realms. It points to the multidimensionality of gender, class, ethnic, and national oppression, and suggests new, and sometimes unconventional, solutions ${ }^{49}$. The general feminist movement exposed the patriarchal structure that deviates from the family sphere and penetrates the religious, labor and state arrangements. Thus, the women's movement linked domestic inequality to labor-market inequality, and initiated a whole series of laws to promote women's equality in the labor market ${ }^{50}$. In Israel, it revealed how the separation between the private and the public enables the exclusion of women from the army and from politics, and, as a result, various bodies of civil society have adopted the goal of political advancement of women ${ }^{51}$. We can see that most of the feminist activity is planted in all arenas of civil society, working to expand the secular-democratic awareness and allow for a pluralistic secular space.

\footnotetext{
${ }^{48}$ Foucault 1971.

${ }^{49}$ Herzog 2006, p. 198.

${ }^{50}$ Izraeli 1999, p. 201.

${ }^{51}$ Herzog 2006, p. 201.
} 


\section{THE PROSPECTIVE STATUS OF WOMEN IN ISRAEL FOLLOWING A CLASH BETWEEN THE FEMINIST AND RELIGIOUS REVOLUTIONS IN THE ISRAELI ARMY}

\section{Summary}

It had taken women in Israel many years and an appeal to the High Court of Justice to improve their status in the Israeli Defense Force (IDF), and receive recognition for their ability to fill essential positions and roles which have hitherto been considered 'masculine.' However, nowadays, there are growing concerns that those achievements of women may suffer a setback as a consequence of an increasing process of radicalization and religionization in Israeli daily life, and especially in the IDF. This development is due to the increased participation in the mandatory military service of Orthodox-religious men, whose worldview is typified by strict notions of religious piety and conservatism that demands gender segregation. Consequently, there is already a growing number of cases in which women are excluded from activities while performing their military duties.

The Israeli discourse on the exclusion of women in the IDF tends to focus on the effects that the radicalization and religionization in the IDF have on women while performing their military service. This article, however, emphasizes the implications that these processes in the IDF have on women's employment opportunities after they complete their military service. It draws attention to the difficulty women have in breaking through the 'glass ceiling', in light of the influence the military service in Israel has on employment opportunities in civilian life in general.

The article concludes that it is imperative to increase awareness of these practices of exclusion among both men and women, and thus reduce or prevent them. The discourse must be changed, and the mechanisms of gender exclusion should be exposed. Accessibility, transparency, public participation, empowerment, and equal opportunity must be advanced. Understanding the phenomenon and looking for ways and solutions to prevent it, will also strengthen women's awareness of their right and their duty to insist that they are treated equally and respectfully.

\section{Bibliography}

Brooke Y. 2012, The Great Challenge of Social Protest [online]. Haaretz [access: 2016-11-02]. Available at: <https://www.haaretz.co.il/1.1719058>.

Carmon T. 2016, Power Is Lacking for Women [online]. Davar [access: 2016-11-02]. Available at: $<$ https://www.davar1.co.il/39117/>.

Cohen S.A., Orr-Yisrael B. 2001, The Societal Consequences of Military Service in Israel: A Reappraisal, Democratic culture 4/5, pp. 131-150. 
Eran-Yonah M., Padan C. 2018, The Service of Women Combatants in the IDF - The Stalled revolution, Strategic Update, 20, 4, pp. 89-100.

Foucault M. 1971, L'ordre du discours, Paris.

Fuchs H. 2016, Gender Gaps in the Labor Market: wages and employment polarization, State of the Nation Report: Society, Economy and Policy 2016, Tel-Aviv, pp. 57-99.

Harel A., Shenrach A. 2003, Separation of the Sexes in Public Transport, Aley Mishpat, 3, pp. 98-71.

Helman S. 2001, Citizenship Regime, Identity and Peace Protest in Israel, [in:] M. Krumer-Nevo, M. Malka, S. Moredechayev (eds.), Military Service of Immigrant Soldiers from Kavkaz: An "Entry Ticket" to Israeli Society or a Reproduction of Ethno-Class Stratification? Israeli Sociology, 14, 2, pp. 313-338.

Herzog H. 2006, Between the Lawn and the Gravel Path - Women, Politics, and Civil Society, Democratic Culture 10, pp. 191-214.

Hosken F.P. 1981, Towards a Definition of Women's Rights, Human Rights Quarterly, 3, 2, pp. $1-10$.

Irshai R. 2018, Dignity, Honor and Equality in Contemporary Halachic Thinking: The Case of Torah Reading by Women in Israeli Modern Orthodoxy, [in:] D. Schwarz, R. Irshai (eds.), A New Spirit in the Palace of Torah. Ramat-Gan, pp. 301-326.

Izraeli D.N. 1999, Gender in the Labor Market, [in:] eadem (ed.), Sex Gender Politics. Tel-Aviv, pp. 167-216.

Jerby I. 1996, The Double Price: The Status of the Woman in Israeli Society and the Service of Women in the IDF, Tel Aviv.

Knesset 2019 [online]. Knesset [access: 2016-11-02]. Available at: <https://m.knesset.gov.il/ about/history/pages/womeninknesset.aspx $>$.

Krumer-Nevo M., Malka M., Moredechayev S. 2013, Military Service of Immigrant Soldiers from Kavkaz: An 'Entry Ticket' to Israeli Society or a Reproduction of Ethno-Class Stratification? Israeli Sociology 14, 2, pp. 313-338.

Levy Y. 2003, The Other Army of Israel: Materialist Militarism in Israel, Israeli Sociology 14,2, pp. 313-338.

Levy Y. 2008, The Law of Apprehensive Integration: A Proposal for a Multi-Dimensional Analysis of the Religious-Women Conflict in the IDF, The Public Space, 2, pp. 132-159.

Levy Y. 2012, Why Did the Exclusion of Women in the Army Develop? [online]. Haaretz [access: 2012-01-02]. Available at: $<$ https://www.idi.org.il/articles/8554>.

Levy Y. 2018, How Eizenkot Institutionalized Religionization in the IDF [online]. Haaretz [access: 2018-01-17]. Available at: <https://www.haaretz.co.il/magazine/the-edge/.premium$1.5743689>$.

Naveh B., Shor Y. 2001, Women in the IDF, [in:] U. Dromi (ed.), Women in the Israel Defense Forces, Jerusalem.

Orpaz I. 2015, 'It Doesn't Pay for Women to Work in High-Tech in Israel': The Amazing Wage Gaps of the Start-Up Nation [online]. The Marker [access: 2015-06-18]. Available at: $<$ https://www.themarker.com/magazine/1.2662795>.

Pinto M. 2013, The Essence of Essential Equality Following the Prozanski affair. Law and Business 16, pp. 109-150.

Rozen Y. 2017, Annual Benchmark Research - Recruitment of Workers in Israel. IKT and HRD Training for Recruitment Ltd., Tel Aviv.

Sasson-Levi O., Amram-Katz S. 2007, Gender Integration in Israeli Officer Training: Degendering and Regendering the Military, Signs: Journal of Women in Culture and Society 33,1, pp. 105-135.

Sasson-Levi O. 2013, Between Exclusion and Separation: Women in the Military Sphere, [in:] R. Halperin (ed.), Where I am: Gender Perspectives on Space, Kfar Saba, pp. 111-141. 
Shafran-Gittleman I. 2018, Women's Service in the IDF: Between the People's Army and Gender Equality [online]. IDI [access: 2018-04-16]. Available at: <https://www.idi.org.il/ parliaments/22242/22247>.

Spiegel U. 2007, Ultra-Orthodox, 'The People' and 'The People's Army': The Discourse about 'recruiting ultra-Orthodox to the army' as an Expression of the Struggle for the Preservation of Collective Identity in Israel, Politika 16, pp. 67-91.

Statman D. 2001, Two Concepts of Dignity, Tel-Aviv University Law Review 24, 3, pp. 603-541.

Wilmovsky I., Tamir T. 2013, Women in Israel - Between Theory and Reality: Trends, Changes, and Data, Jerusalem.

Yefet K.C., Almog S. 2016, Religionization, Exclusion, and the Military: Zero in Gender Relations, Studies of Law 39, pp. 243-316. 